\title{
A Large-Scale Survey of the Bacterial Communities in Lakes of Western Mongolia with Varying Salinity Regimes
}

\author{
Kshitij Tandon ${ }^{1,2,3, \dagger}$, Bayanmunkh Baatar ${ }^{1,4,+}{ }^{,}$Pei-Wen Chiang ${ }^{1}$, Narangarvuu Dashdondog ${ }^{4}$, \\ Bolormaa Oyuntsetseg ${ }^{4, *}$ and Sen-Lin Tang ${ }^{1,2, *}$ \\ 1 Biodiversity Research Center, Academia Sinica, Taipei 115, Taiwan; kshitijtandon@gate.sinica.edu.tw (K.T.); \\ b.bayanmunkh@mnun.edu.mn (B.B.); momo12390@gmail.com (P.-W.C.) \\ 2 Bioinformatics Program, Institute of Information Science, Taiwan International Graduate Program, \\ Academia Sinica, Taipei 115, Taiwan \\ 3 Institute of Molecular and Cellular Biology, National Tsing Hua University, Hsinchu 300, Taiwan \\ 4 School of Arts and Sciences, National University of Mongolia, Ulaanbaatar 14201, Mongolia; \\ garvuu@num.edu.mn \\ * Correspondence: bolormaa@num.edu.mn (B.O.); sltang@gate.sinica.edu.tw (S.-L.T.) \\ + These authors contributed equally to this work.
}

Received: 19 October 2020; Accepted: 3 November 2020; Published: 4 November 2020

\begin{abstract}
In recent years, climate change coupled with anthropogenic activities has led to monumental changes in saline lakes which are rapidly drying up across the globe and particularly in Central Asia. The landlocked country of Mongolia is rich in lakes which have remained primarily undisturbed by human impact, and many of these lakes have varying salinity regimes and are located across various geographical landscapes. In this study, we sampled 18 lakes with varying salinity regimes (hyperhaline, mesohaline, oligohaline, and polyhaline) covering $7000 \mathrm{~km}$ of western Mongolia and its various geographical landscapes (Gobi Desert, forests, and steppe). We identified that the bacterial communities that dominate these lakes are significantly influenced by salinity $(p<0.001)$ and geographical landscape $(p<0.001)$. Further, only five zOTUs were shared in all the lakes across the salinity regimes, providing evidence that both local and regional factors govern the community assembly and composition. Furthermore, the bacterial communities of hyperhaline lakes were significantly positively correlated with salinity (ANOVA, $p<0.001$ ) and arsenic concentrations (ANOVA, $p<0.001$ ), whereas bacterial communities of mesohaline and polyhaline lakes situated in forest and steppe landscapes were positively correlated with temperature (ANOVA, $p<0.001$ ) and altitude (ANOVA, $p<0.001$ ), respectively. Functional predictions based on the 16S rRNA gene indicated enrichment of KEGG Ontology terms related to transporters for osmoprotection and -regulation. Overall, our study provides a comprehensive view of the bacterial diversity and community composition present in these lakes, which might be lost in the future.
\end{abstract}

Keywords: bacterial community; saline lakes; western Mongolia; Cyanobium-PCC6307; Halomonas; Spiribacter; local and regional factors

\section{Introduction}

Lakes form a major proportion of aquatic ecosystems on a global scale. In particular, saline lakes account for $\sim 44 \%$ and $\sim 23 \%$ of the total volume and area of global lakes, respectively. These saline lakes are predominantly located in arid, endorheic basins [1]. Furthermore, these lakes are sentinels for anthropogenic activities and associated global warming [2]. In recent years, saline lakes around the world have seen a significant decline, including those present in remote areas of the Mongolian 
Plateau [1,3]. The effect of global warming on lakes is complemented by the removal of freshwater from lake drainage areas for agricultural, industrial, and municipal applications [4], leading to increased evaporation rates and over-salting [5]. While these activities change the biogeochemical properties of lakes, they also affect the lakes' microbial diversities. Since microbes contribute significantly to the biogeochemical cycles at a global scale [6], it is important to study and delineate the microbial diversity. Identification of the microbial communities of saline lakes which are some of the most extreme environments on our planet can provide vital information on the evolution of life on Earth, as well as help understand the ecological mechanisms that help maintain the lake's functional ecosystems [7].

Microorganisms-including bacteria, archaea, and microalgae-form the basis of lake ecosystems [5]. Over the years, sequencing approaches have been used to understand the biogeographical distribution of microbial communities in both freshwater [8-12] and saline lakes [13-18]. Within lakes and especially saline lakes, microorganisms are important members with their high genetic diversity playing an essential role in element cycling $[19,20]$. Salinity has been attributed as one of the major factors (local) influencing the microbial community assembly in saline lake waters [9,21-24]. Interestingly, the considerable similarity between the biota of freshwater and saline lakes is present between salinity levels of 3 and $20 \mathrm{~g} \cdot \mathrm{L}^{-1}$. However, with an increase in salinity levels, the microbial community composition of saline lakes diverges from that of freshwater lakes across all taxonomic ranks [25]. Apart from local environmental factors such as salinity, regional factors have also been used to understand the microbial community assembly. Geographical factors have also been known to influence the microbial community assembly with varying scales. Comparison of clone libraries from lakes of Inner Mongolia and Argentina and biogeographical populations of halophilic Nocardiopsis and Streptomyces isolated from lakes in Central Asia showed geographical variation after more than $700 \mathrm{~km}$ [26,27]. Meanwhile, Zorz et al. [17] identified that soda lakes located thousands of kilometers apart have a strikingly similar microbiome. These contrasting results provide scope to compare microbial communities of lakes with varying salinity regimes separated by hundreds of kilometers and located in diverse geographical landscapes to provide detailed insights into the factors governing the microbial community composition.

Mongolia, a landlocked country, is abundant in extremely oligotrophic and saline lakes [28]. Western Mongolia has $~ 3500$ lakes, and more than half are estimated to be saline [28,29]. Western Mongolia has a rich variety of geographical landscapes, including the Gobi Desert and steppe and high mountain environments, and an overall extremely harsh, dry climate with a yearly average precipitation of only $\sim 194 \mathrm{~mm}$. Therefore, lakes in this region have remained relatively untouched from scientific and anthropogenic activity, making them an excellent research environment to explore diversity in high-latitude saline environments and perform a comparative analysis of microbial community compositions. In recent years, anthropogenic activity-especially mining-coupled with global warming has increased the average temperature in the region by 3 to $5{ }^{\circ} \mathrm{C}$. Recent studies have profiled the chemical compositions of 18 saline lakes in western Mongolia [30,31]. However, the microbial community composition of these lakes remains elusive.

In the present study, we examined the bacterial community composition of 18 saline lakes in western Mongolia crisscrossing $7000 \mathrm{~km}$. We sampled across depths of lakes and sequenced 16S rRNA gene amplicons of these samples using paired-end 454 pyrosequencing. This large-scale survey enriches our knowledge of the bacterial community composition of saline lakes situated in Central Asia and attempts to decipher the influence of various salinity regimes and geographical landscapes on the bacterial communities of high-altitude saline lakes. Furthermore, this study will also serve as a vital resource on the microbial community composition of Mongolian lakes, which are experiencing rapid shrinking and are believed to be lost in the future [3]. 


\section{Materials and Methods}

\subsection{Study Sites and Sampling}

We performed sampling in the summer of 2012-2013, the first trip in September 2012 and the second in July 2013, across a large compressional basin bound by the Khangai Mountains, Altai Mountains, a valley of the Great Lakes, and the Gobi Desert in the eastern, western, northern, and southern parts of western Mongolia, respectively. In total, we covered $\sim 7000 \mathrm{~km}$ and collected 72 water samples from 18 lakes spanning different salinity regimes (Figure 1). Six-liter lake water samples were vertically collected from each sampling depth at a $1 \mathrm{~m}$ interval (at times 0.5 and $0.25 \mathrm{~m}$ ) using a handmade vacuum deep-water sampler, similar to an earlier study [9]. Collected water samples were retained in $6 \mathrm{~L}$ sterile containers and directly transported to the field station (located on the shore of each lake). Water samples were first filtered using a piece of gauze (to remove large debris; $10 \mu \mathrm{m}$ plankton net), then retentates were filtered with $0.22 \mu \mathrm{m}$ polycarbonate membrane filters using a vacuum pump at the field station. These membranes were further air-dried at room temperature for 15 min or more and later sealed in separate sterile bags until arrival at the laboratory for DNA extraction.

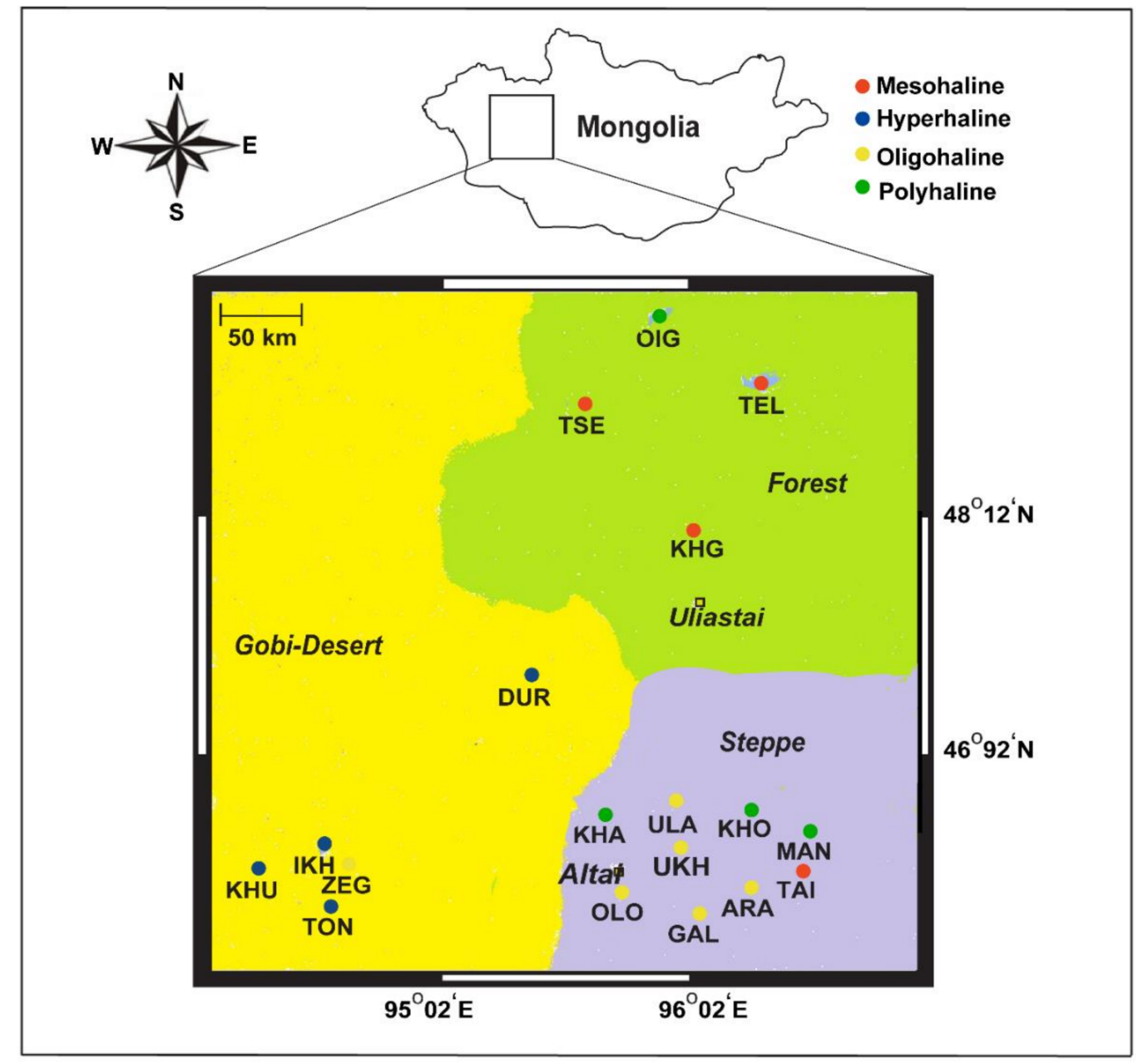

Figure 1. Map showing 18 lakes sampled from western Mongolia, their geographical landscapes (Gobi Desert, forests, and steppe), and their different salinity regimes (hyperhaline, mesohaline, polyhaline, and oligohaline). 


\subsection{DNA Extraction, Library Preparation, and Sequencing}

Total DNAs were extracted using the cetyltrimethylammonium bromide (CTAB) method. The quality and quantity of extracted nucleic acids were measured using a ScanDrop spectrophotometer (Thermo Scientific, Vantaa, Finland). 16S rRNA gene V6-V8 hypervariable region amplification was performed using the bacterial universal primers 968F (5'-AACGCGAAGAACCTTAC-3') [32] and 1391R (5'-ACGGGCGGTGWGTRC-3') [33]

The reaction mixture contained $2.5 \mathrm{U}$ of TaKaRa Ex taq ${ }^{\mathrm{TM}} \mathrm{HS}$ (Takara Bio, Otsu, Japan), $200 \mu \mathrm{M}$ of each dNTP, $0.2 \mu \mathrm{M}$ of each primer, and 2-5 ng of diluted template DNA (final concentration: $100 \mathrm{ng} / \mathrm{L}$ ). PCR was performed under the following conditions: $94{ }^{\circ} \mathrm{C}$ for $5 \mathrm{~min}, 20$ cycles at $94{ }^{\circ} \mathrm{C}$ for $30 \mathrm{~s}, 72{ }^{\circ} \mathrm{C}$ for $45 \mathrm{~s}$, with a final step at $72{ }^{\circ} \mathrm{C}$ for $10 \mathrm{~min}$, and cooling at $4{ }^{\circ} \mathrm{C}$.

The PCR products of the bacterial 16S rRNA gene's V6-V8 region were verified by DNA agarose gel electrophoresis with a $1 \%$ agarose gel with $1 X$ TE buffer and SYBR ${ }^{\circledR}$ Green I. Expectedly sized products $(\sim 423 \mathrm{bp})$ were cut from the gel and purified using a QIAEX II Gel Extraction Kit (Qiagen, Valencia, CA, USA), and quality was verified with a NanoDrop spectrophotometer (Thermo Scientific, Vantaa, Finland).

DNA-tagging PCR was used to tag each PCR product. Seventy-two unique sample-specific four-nucleotide barcodes were added to the $5^{\prime}$ ends of $968 \mathrm{~F}$ and $1391 \mathrm{R}$ primers of each sample. The tagging PCR consisted of an initial step at $94{ }^{\circ} \mathrm{C}$ for $5 \mathrm{~min}$, followed by 5 cycles at $94{ }^{\circ} \mathrm{C}$ for $30 \mathrm{~s}, 54{ }^{\circ} \mathrm{C}$ for $20 \mathrm{~s}$, and $72{ }^{\circ} \mathrm{C}$ for $4 \mathrm{~s}$, with a final step at $72{ }^{\circ} \mathrm{C}$ for $10 \mathrm{~min}$, and then cooling at $4{ }^{\circ} \mathrm{C}$. Finally, PCR products were pooled and a $1200 \mathrm{ng}$ mixture of tagged V6-V8 amplicons was subjected to pyrosequencing (Roche GS454 FLX Titanium, Mission Biotech, Taipei, Taiwan).

\subsection{Measurement and Analysis of Physical and Chemical Parameters}

For each lake and depth, both physical and chemical parameters were measured as described previously [30,31]. In brief, temperature, dissolved oxygen, $\mathrm{pH}$, and salinity were measured using a Hanna HI 9828 multiparameter meter (Hanna Instruments, Woonsocket, RI, USA). The pH sensor was calibrated with a $3 \mathrm{M} \mathrm{KCl}$ calibration solution (Hanna instruments) each time before measurement. Trace and minor elements in water samples were analyzed by Inductively coupled plasma-mass spectrometry X-Series 2 (Thermo Scientific, Berlin, Germany) in an accredited laboratory (Central Geological Laboratory of Mongolia). Physicochemical parameters used in this study are provided in Supplementary Table S1.

\subsection{Data Analysis}

Reads obtained from paired-end pyrosequencing were quality-filtered with MOTHUR v1.38.1 [34] on a per-sample basis. Quality-filtered reads (minimum length: 360 bp, maximum length: 460 bp, qaverage $>27$, homopolymer length $<6$ ) were retained for downstream analysis. Chimeric reads were detected and removed using UCHIME [35] by USEARCH v11 [36], and singletons were also discarded. Qualified sequences were retained for further analysis. Qualified and non-chimeric reads were analyzed with UNOISE3 [37] to obtain zero-radius operational taxonomic units (zOTUs) which are equivalent to amplicon sequence variants. zOTUs were classified with taxonomic labels from the SILVA132 $[38,39]$ database in Mothur on a per-sample basis with a pseudo-bootstrap cutoff of $80 \%$. zOTUs belonging to eukaryote, chloroplast, mitochondria, and unknown were removed before community composition analyses. Bacterial diversity (Shannon and Simpson), richness (Chao1), and evenness (Peilou's evenness) were calculated using zOTU abundance profiles rarified across all samples. Statistical analysis on $\alpha$-diversity was performed with the Kruskal-Wallis test, $p<0.05$.

The relative abundance of zOTUs at the phylum and genus levels was calculated on unrarefied data using an in-house R script ( $R$ Team 2018). Bubble plots were generated for the most abundant taxa (genus: $>0.01 \%$ relative abundance) across all sampling layers of the 18 lakes using ggplot2 [40]. Beta-diversity estimation using non-metric multidimensional scaling (nMDS) analysis was performed 
after $\log (x+1)$ transforming the zOTU table and calculating Bray-Curtis distance using phyloseq [41] in R. PERMANOVA (using Adonis function) and ANOVA analyses were performed using the vegan package [42] to statistically determine the relationships among bacterial communities and their separation based on salinity type and geographic landscape. Furthermore, zOTUs present in at least $50 \%$ of samples with a minimum of 5 reads were used to determine the core bacterial community shared in lakes.

Additionally, functional predictions based on 16S rRNA gene data were performed with the Tax4Fun2 [43] package in R. Tax4Fun2 calculates the metabolic potential of identified microbial taxa by linking taxonomy and abundance profile to a KEGG Orthology (KO) database. Metabolic pathway abundance was normalized by $16 \mathrm{~S}$ rRNA copy number and used as input to the shotgun data profiling plugin of the web-based tool MicrobiomeAnalyst [44,45]. A linear discriminant analysis (LDA) effect size (LEfSe) analysis was performed to analyze differences in metabolic pathways between different salinity regimes. Statistical significance was tested at the LDA score threshold of $>3.5$ and $p<0.05$.

Environmental factors, including physicochemical parameters, were checked for collinearity using Spearman's rank correlation. Factors with low correlations $(r<0.5)$ were selected for canonical correspondence analysis (CCA) to explore the contributions of these environmental parameters to community structure. Furthermore, ANOVA analysis was performed to assess the significance of constraint variables.

\section{Results}

Water chemistry may help better explain the status of lakes, extrapolate potential interactions between lake water and local geological factors, and assess the impact of anthropogenic activities on aquatic environments. We analyzed the physicochemical profiles of samples from 18 lakes across depths in western Mongolia (Supplementary Table S1). Notably, we categorized the lakes into four types based on salinity: hyperhaline, polyhaline, mesohaline, and oligohaline (Table 1), as outlined by the U.S Fish \& Wildlife Service. These lakes were also different in several physicochemical parameters, including temperature, $\mathrm{pH}$, dissolved oxygen, and arsenic concentration. A higher concentration of arsenic was detected in hyperhaline lakes and was particularly high $(0.34 \mathrm{mg} / \mathrm{L})$ in Lake Tonkhil (TON). Notably, lakes in forest landscapes were deeper than those in the Gobi Desert and steppe landscapes (Supplementary Table S1).

\subsection{Bacterial Community Diversity and Richness}

In total, we observed 663 zOTUs from 182,751 qualified sequences from 72 samples of 18 saline lakes. Of the 663 zOTUs identified, 6 were eukaryotes, 10 were unknown, 3 belong to the chloroplast, and 644 zOTUs were used for alpha diversity analysis. Samples were rarified to an equal depth of 395 reads. Shannon diversity index ranged from 2.46 to 3.83 in mesohaline lakes, 2.69 to 3.46 in oligohaline lakes, 2.31 to 3.49 in polyhaline lakes, and 1.69 to 3.03 in hyperhaline lakes, indicating lower diversity in hyperhaline lakes compared to others. Simpson index ranged from 0.03 to 0.20 in mesohaline, 0.04 to 0.15 in oligohaline, 0.05 to 0.20 in polyhaline, and 0.06 to 0.37 in hyperhaline lakes. Both of these measures were significantly different between lakes of different salinity regimes, Kruskal-Wallis test, $p<0.05$ (Figure 2a,b).

The Chao1 index, which estimates the number of species that are represented only by a single individual or singletons, and Peilou's evenness indices, a measure of equality of a community, had a range of 61.9.1-93.3 and 0.71-0.85 in oligohaline lakes, 31.1-152.1 and 0.64-0.84 in polyhaline lakes, 49.5-144.6 and 0.64-0.89 in mesohaline lakes, and 30.0-54.1 and 0.53-0.87 in hyperhaline lakes, respectively. The Chao1 index was significantly different between hyperhaline vs. oligohaline, mesohaline, and polyhaline lakes; oligohaline vs. mesohaline lakes, and mesohaline vs. polyhaline lakes (Kruskal-Wallis test, $p<0.05$ ) (Figure 2c), whereas Peilou's evenness index was significantly different between polyhaline vs. oligohaline and mesohaline lakes (Kruskal-Wallis test, $p<0.05$ ) (Figure 2d) only. 
Table 1. Location of sampling sites, their altitude, landscape, and abbreviated codes.

\begin{tabular}{|c|c|c|c|c|c|c|}
\hline Salinity & $\begin{array}{l}\text { Lake Name } \\
\text { (Trip) }\end{array}$ & Code & Latitude N & Longitude E & Altitude (m) & Landscape \\
\hline \multirow{4}{*}{ Hyperhaline } & Khulma (1) & $\mathrm{KHU}$ & $46^{\circ} 11^{\prime} 01$ & $93^{\circ} 32^{\prime} 39$ & 2224 & Gobi Desert \\
\hline & Tonkhil (1) & TON & $46^{\circ} 11^{\prime} 08$ & $93^{\circ} 54^{\prime} 16$ & 2063 & Gobi Desert \\
\hline & Ikhes (1) & IKH & $46^{\circ} 27^{\prime} 39$ & $94^{\circ} 03^{\prime} 54$ & 1601 & Gobi Desert \\
\hline & Duruu (1) & DUR & $47^{\circ} 16^{\prime} 45$ & $95^{\circ} 42^{\prime} 35$ & 1425 & Gobi Desert \\
\hline \multirow{4}{*}{ Polyhaline } & Mangas (1) & MAN & $46^{\circ} 29^{\prime} 52$ & $96^{\circ} 47^{\prime} 47$ & 1760 & Steppe \\
\hline & Kholboo (1) & $\mathrm{KHO}$ & $46^{\circ} 24^{\prime} 02$ & $97^{\circ} 18^{\prime} 51$ & 1799 & Steppe \\
\hline & Khadaasan (1) & KHA & $46^{\circ} 30^{\prime} 25$ & $96^{\circ} 17^{\prime} 16$ & 2003 & Steppe \\
\hline & Oigon (1) & OIG & $49^{\circ} 09^{\prime} 03$ & $96^{\circ} 31^{\prime} 36$ & 1668 & Forest \\
\hline \multirow{4}{*}{ Mesohaline } & Taigam (1) & TAI & $46^{\circ} 22^{\prime} 09$ & $97^{\circ} 24^{\prime} 06$ & 1790 & Steppe \\
\hline & Telmen (2) & TEL & $48^{\circ} 51^{\prime} 37$ & $97^{\circ} 19^{\prime} 34$ & 1795 & Forest \\
\hline & Tsegeen (2) & TSE & $48^{\circ} 44^{\prime} 00$ & $95^{\circ} 51^{\prime} 32$ & 1875 & Forest \\
\hline & Khag (2) & KHG & $48^{\circ} 04^{\prime} 29$ & $96^{\circ} 38^{\prime} 28$ & 2036 & Forest \\
\hline \multirow{6}{*}{ Oligohaline } & Zegst (1) & ZEG & $46^{\circ} 12^{\prime} 18$ & $93^{\circ} 55^{\prime} 35$ & 2066 & Gobi-Desert \\
\hline & Olon (1) & OLO & $46^{\circ} 18^{\prime} 49$ & $96^{\circ} 22^{\prime} 13$ & 2185 & Steppe \\
\hline & Galuut (2) & GAL & $46^{\circ} 18^{\prime} 03$ & $96^{\circ} 42^{\prime} 23$ & 2034 & Steppe \\
\hline & Argashuun (1) & ARA & $46^{\circ} 28^{\prime} 54$ & $97^{\circ} 08^{\prime} 01$ & 1798 & Steppe \\
\hline & Ulaan (1) & ULA & $46^{\circ} 27^{\prime} 20$ & $96^{\circ} 17^{\prime} 08$ & 1996 & Steppe \\
\hline & Ulaan- Kholboo (1) & $\mathrm{UKH}$ & $46^{\circ} 27^{\prime} 10$ & $96^{\circ} 17^{\prime} 01$ & 1997 & Steppe \\
\hline
\end{tabular}

Altitude (m)-above sea level.
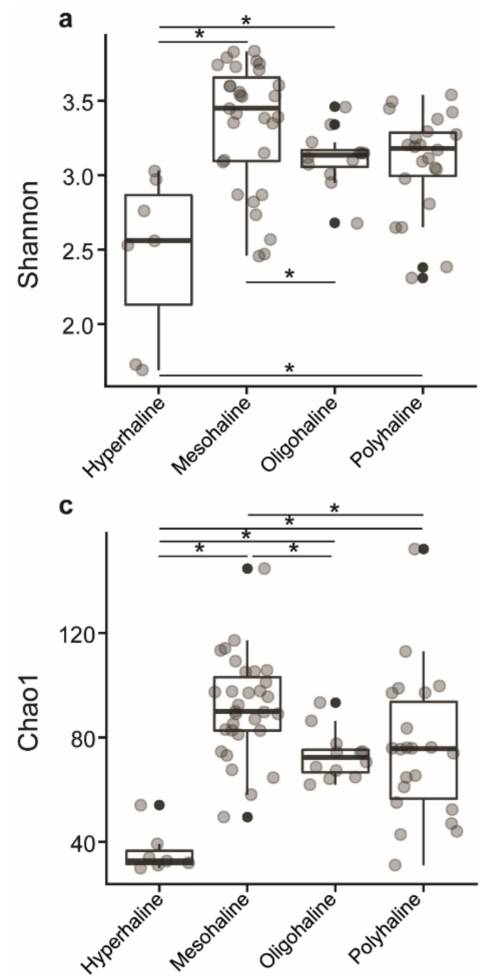

b

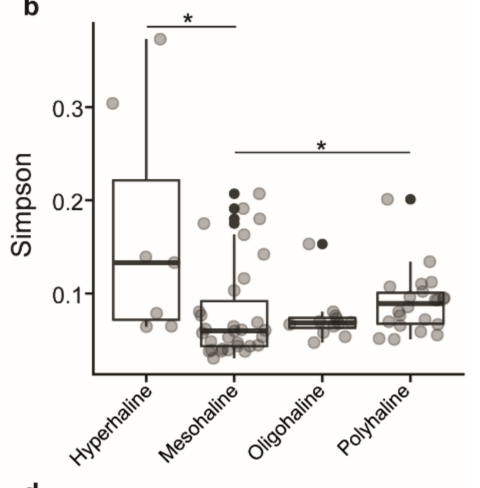

d

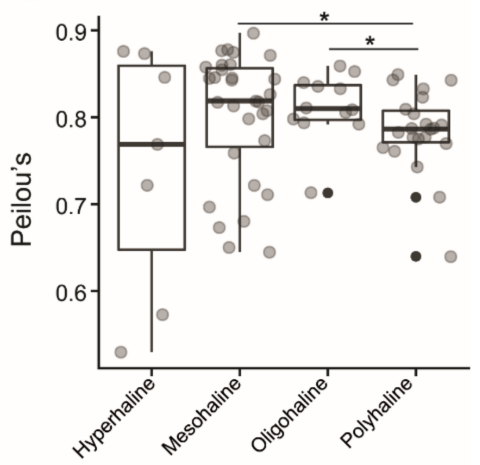

Figure 2. Boxplot of alpha-diversity indices. (a) Shannon and (b) Simpson indices reflect the diversity of zOTUs in samples. (c) Chao1 and (d) Peilou's indices reflect the zOTU abundance and evenness in samples. The greater the Shannon and Simpson indices, the higher the diversity of the microbiota in samples. The greater the Chao1 and Peilou's indices, the higher the expected species richness and evenness of the microbiota; boxes represent the interquartile range (IQR) between the first and third quartiles (25th and 75th percentiles, respectively), and the horizontal line inside the box defines the median. Whiskers represent the lowest and highest values within 1.5 times the IQR from the first and third quartiles, respectively. "•" indicates greater than 1.5 times and less than three times the IQR; Grey circles denote respective alpha diversity estimate values of lake samples grouped based on their salinity; “*”: significant difference was tested with the Kruskal-Wallis test, $p<0.05$. 


\subsection{Bacterial Community Composition of Western Mongolian Lakes}

Out of 644 zOTUs, 18 zOTUs remained unclassified at the phylum level, leaving 626 bacterial zOTUs. These 626 zOTUs were used for downstream analysis. Bacterial community members consisted of 15 phyla and 28 classes, including 4 classes that remained unclassified beyond the phylum. The relative abundance of bacterial communities was determined at each taxonomic level. At the phylum level, Proteobacteria, Actinobacteria, Bacteroidetes, and Cyanobacteria were dominant. These phyla constituted $>90 \%$ of the total bacterial community in each lake. Actinobacteria, Bacteroidetes, and Proteobacteria were identified in all lakes. Phylum Cyanobacteria was dominant in polyhaline and mesohaline lakes. Proteobacteria was the dominant group in hyperhaline lakes (average (avg.) relative abundance $\sim 63 \%$ ) and oligohaline lakes ( $\sim 40 \%$ avg. relative abundance), followed by Bacteroidetes (hyperhaline: $\sim 30 \%$; oligohaline: $\sim 15 \%$ ). Cyanobacteria were detected mainly in deeper lakes and were particularly dominant in mesohaline lakes across all depths and the oxic zone (0-7 m) of Lake Oigon (OIG), a polyhaline lake. Actinobacteria was another major group in mesohaline ( $22 \%$ avg. relative abundance), polyhaline ( $\sim 22 \%$ average relative abundance), and oligohaline ( $\sim 18 \%$ relative abundance) lakes, but were quite rare in hyperhaline lakes. Many of the dominant phyla were specific to certain lakes. For example, the phylum Halanaerobiaeota was only abundant in hyperhaline lakes $(\sim 3.5 \%$ avg. relative abundance). Planctomycetes were dominant only in mesohaline lakes $(\sim 1.7 \%$ avg. relative abundance) (Figure 3a).

Bacterial genera belonging to classes Actinobacteria, Alpha- and Gamma-Proteobacteria, Bacteroidia, Nitriliruptoria, Oxyphotobacteria, and Verrucomicrobiae were the most dominant across all lakes (>0.01\% relative abundance). Cyanobium-PCC-6307 (class: Oxyphotobacteria) was dominant across all depths in mesohaline lakes ( $27.6 \%$ avg. relative abundance) and Lake Oigon, whereas Pseudomonas ( $11 \%$ avg. relative abundance) and Flavobacterium ( $13 \%$ avg. relative abundance) were dominant in oligohaline lakes. Polyhaline lakes (except Lake Oigon) harbored unclassified Microbacteriaceae as the dominant group. Psychroflexus ( $21.5 \%$ avg. relative abundance), Spiribacter ( $27 \%$ avg. relative abundance), and Halomonas ( $12 \%$ avg. relative abundance) were dominant genera in hyperhaline lakes (Figure 3b).

Furthermore, the shared microbiome among lakes of western Mongolia was deciphered based on the presence of zOTUs in at least $50 \%$ of samples with a minimum of five reads, which resulted in only five zOTUs (zOTU12, zOTU23, zOTU64, zOTU88, zOTU556). zOTU12 belongs to the genus Loktanella (class: $\alpha$-Proteobacteria) and is one of the dominant zOTUs (avg. relative abundance 3.2\%), while zOTU23, zOTU64, zOTU88, and zOTU556 had avg. relative abundances of 2.0\%, 1.39\%, $1.16 \%$, and $0.35 \%$, respectively, across 72 samples. zOTU23 and zOTU88 belong to Microbacteriaceae (unclassified), zOTU64 was annotated to the Candidatus Aquiluna genus, and zOTU556 belongs to unclassified Burkholderiaceae.

\subsection{Local, Regional, and Environmental Drivers of Bacterial Community}

We used nMDS (based on Bray-Curtis dissimilarity) to compare microbial community compositions among the lakes. At the zOTU level, we observed distinct clusters among lakes based on salinity (Figure 4 ) and geographical landscape. Both salinity $(p<0.001)$ and geographical landscape $(p<0.0001)$ were significant factors driving community composition in the lakes of western Mongolia.

Canonical correspondence analysis (CCA) was used to determine the relationships among the environmental variables of each of the lakes, as well as associations between microbial taxa (at the genus level) and physicochemical parameters. Environmental factors ( $\mathrm{pH}$, altitude, dissolved oxygen, arsenate, depth, salinity, temperature) were selected based on correlation values $>0.5$ (Supplementary Figure S1) to perform CCA. Ordination plots show that the bacterial communities were influenced by several environmental factors, such as $\mathrm{pH}$, depth, and salinity (Figure 5). Samples were grouped based on salinity and geographical landscape. Moreover, CCA analysis also indicated that bacterial communities of hyperhaline lakes were significantly associated with arsenic and salinity levels. 
Furthermore, we observed that lakes in the forest landscape were more tightly clustered than those in the Gobi Desert and steppe landscapes (Figure 5).

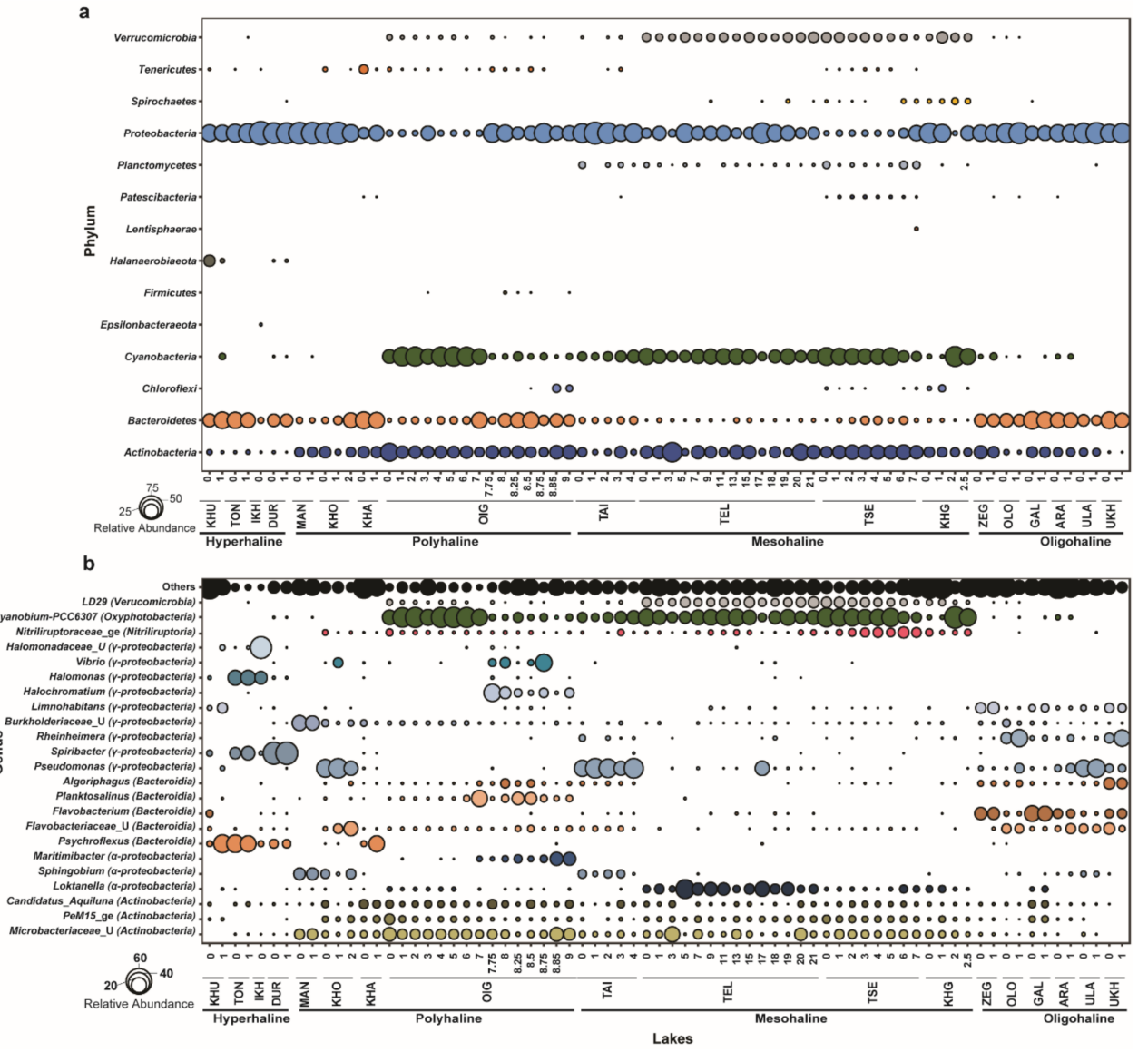

Figure 3. Bacterial community composition of lakes in western Mongolia. (a) Relative abundance of bacterial communities at the phylum level (all phyla). (b) Relative abundance $(>0.01 \%$ relative abundance) of bacterial communities at the genus level; taxonomic classes mentioned in brackets.

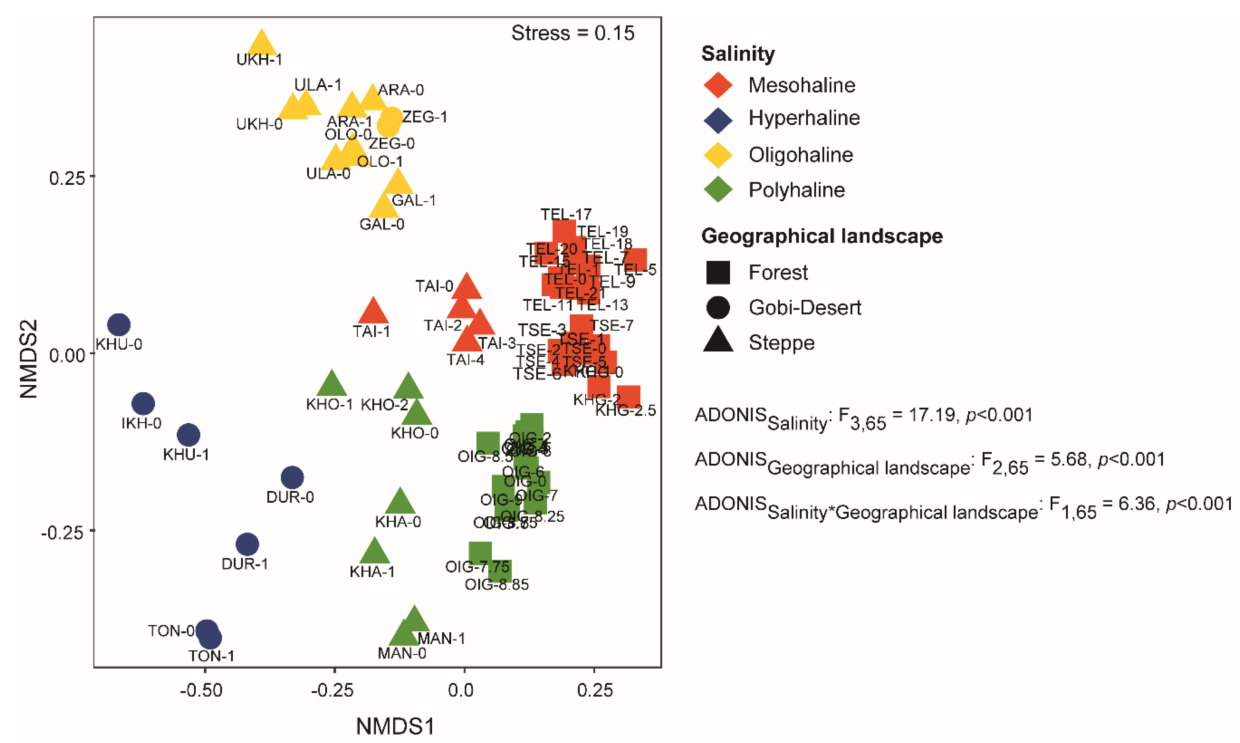

Figure 4. Non-metric multidimensional scaling (nMDS) analysis using Bray-Curtis dissimilarity clustered samples based on salinity and geographical landscape. PERMANOVA analysis was conducted to identify the significant factors shaping the bacterial communities in lakes of western Mongolia. 


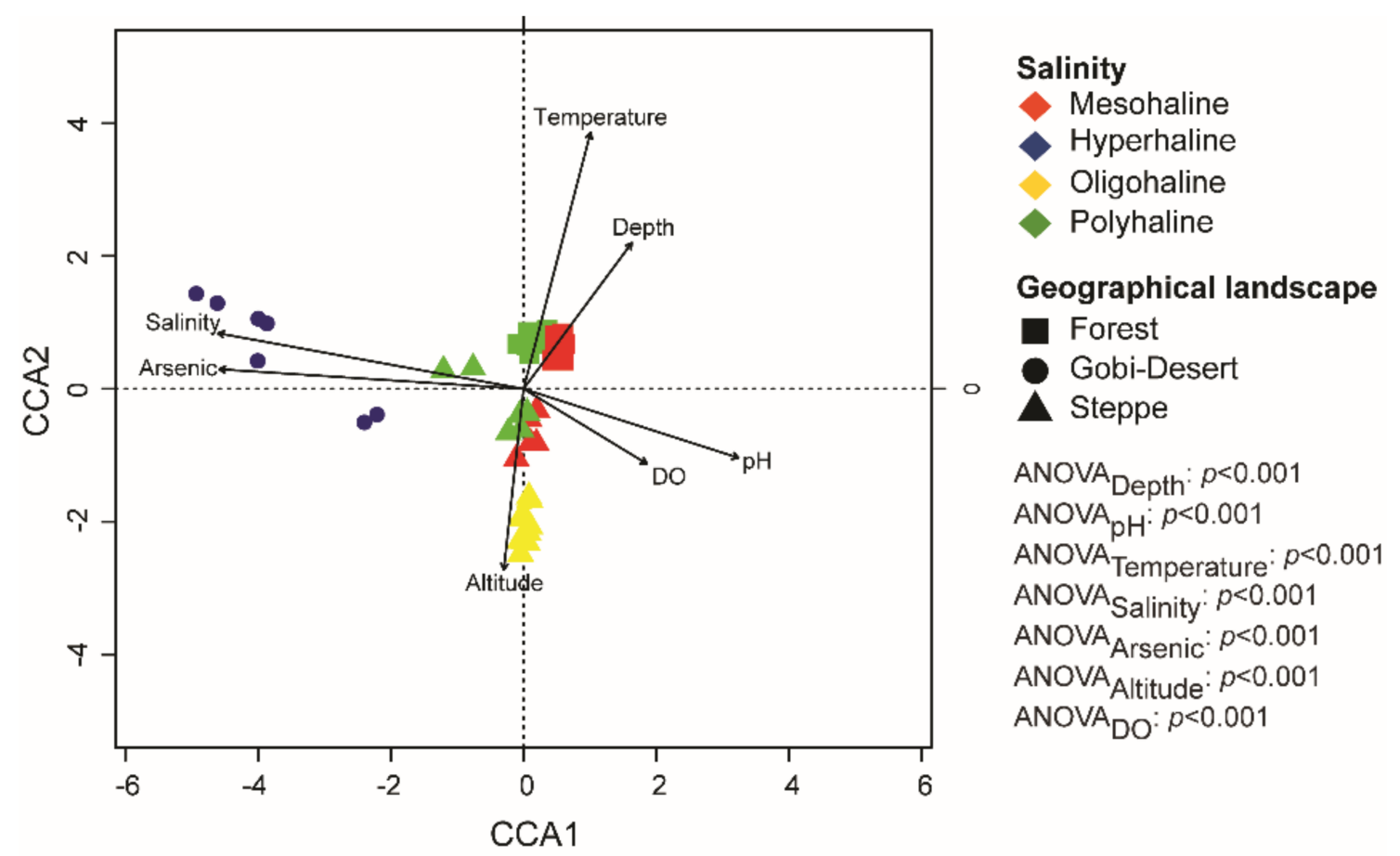

Figure 5. Canonical correspondence analysis (CCA) plot at the genus level. ANOVA analysis was performed to identify the significant environmental factors influencing bacterial communities in lakes of western Mongolia.

\subsection{Functional Predictions}

$16 \mathrm{~S}$ rRNA-based functional predictions of the bacterial community identified $6837 \mathrm{KO}$ identifiers. After a low variance filter, $681 \mathrm{KO}$ identifiers were removed, and the remaining 6156 features were scaled (using total sum scaling) before LEfSe analysis. The LEfSe analysis identified only $17 \mathrm{KO}$ identifiers significantly divergent among different salinity lakes (LDA score threshold of $>3.5$, FDR-corrected $p<0.05$ ). Hyperhaline lakes had five KO identifiers (K00986, K03821, K05568, K06204, K16012) which were significantly divergent. Mesohaline lakes had six KO identifiers which were significantly divergent (K01772, K01915, K0387, K07487, K07497, K10441) and polyhaline lakes also had six significantly divergent KO identifiers (K00854, K05685, K05845, K05846, K09691), and there were no significant identifiers in oligohaline lakes (Figure 6). Most of the significantly divergent $\mathrm{KO}$ identifiers belong to ATP-Binding Cassette (ABC) transporters (K05568, K16012, K10441, K05685, K09691, K05845, and K05846) (Table 2).

Table 2. Differentially abundant KO identifiers in different salinity regimes, their KEGG annotation, and pathways.

\begin{tabular}{|c|c|c|c|}
\hline KO Identifier & KEGG Orthology & KEGG Pathway/BRITE & $\begin{array}{l}\text { Salinity } \\
\text { Regime }\end{array}$ \\
\hline K00986 & RNA-directed DNA polymerase & Unclassified * & Hyperhaline \\
\hline K16012 & ATP-binding Cassette, CydC & $\mathrm{ABC}$ transporters & Hyperhaline \\
\hline K06204 & DnaK suppressor protein & Biofilm formation & Hyperhaline \\
\hline K05568 & Multicomponent $\mathrm{Na}^{+}: \mathrm{H}^{+}$antiporter & Transporters & Hyperhaline \\
\hline K03821 & Polyhydroxyalkanoate-synthase subunit PhaC & Butanoate metabolism & Hyperhaline \\
\hline K07497 & Putative transposase & Unclassified & Mesohaline \\
\hline K10441 & Ribose transport system ATP-binding protein & $\mathrm{ABC}$ transporter & Mesohaline \\
\hline K07487 & Transposase & Unclassified & Mesohaline \\
\hline K03087 & $\begin{array}{l}\text { RNA polymerase nonessential primary-like sigma } \\
\text { factor protein }\end{array}$ & Biofilm formation & Mesohaline \\
\hline K01772 & Protoporphyrin/coproporphyrin ferrochelatase & Porphyrin and chlorophyll metabolism & Mesohaline \\
\hline K01915 & Glutamine synthetase & Carbohydrate metabolism & Mesohaline \\
\hline
\end{tabular}


Table 2. Cont.

\begin{tabular}{|c|c|c|c|}
\hline KO Identifier & KEGG Orthology & KEGG Pathway/BRITE & $\begin{array}{l}\text { Salinity } \\
\text { Regime }\end{array}$ \\
\hline K05845 & $\begin{array}{l}\text { Osmoprotectant transport system substrate-binding } \\
\text { protein }\end{array}$ & $\mathrm{ABC}$ transporters & Polyhaline \\
\hline K05846 & $\begin{array}{l}\text { Osmoprotectatnt transport system substrate-binding } \\
\text { protein }\end{array}$ & $\mathrm{ABC}$ transporters & Polyhaline \\
\hline K07668 & $\begin{array}{c}\text { Two-component system, OmpR family, response } \\
\text { regulator VicR }\end{array}$ & Two-component system & Polyhaline \\
\hline K00854 & Xylulokinase & $\begin{array}{l}\text { Pentose and glucuronate } \\
\text { interconversions }\end{array}$ & Polyhaline \\
\hline K09691 & $\begin{array}{l}\text { Lipopolysaccharide transport system } \\
\text { ATP-binding/permease protein }\end{array}$ & $\mathrm{ABC}$ transporters & Polyhaline \\
\hline K05685 & $\begin{array}{l}\text { Macrolide transport system ATP-binding/permease } \\
\text { protein }\end{array}$ & $\mathrm{ABC}$ transporters & Polyhaline \\
\hline
\end{tabular}

* Unclassified: not classified in "Pathways" or BRITE in the KEGG database.

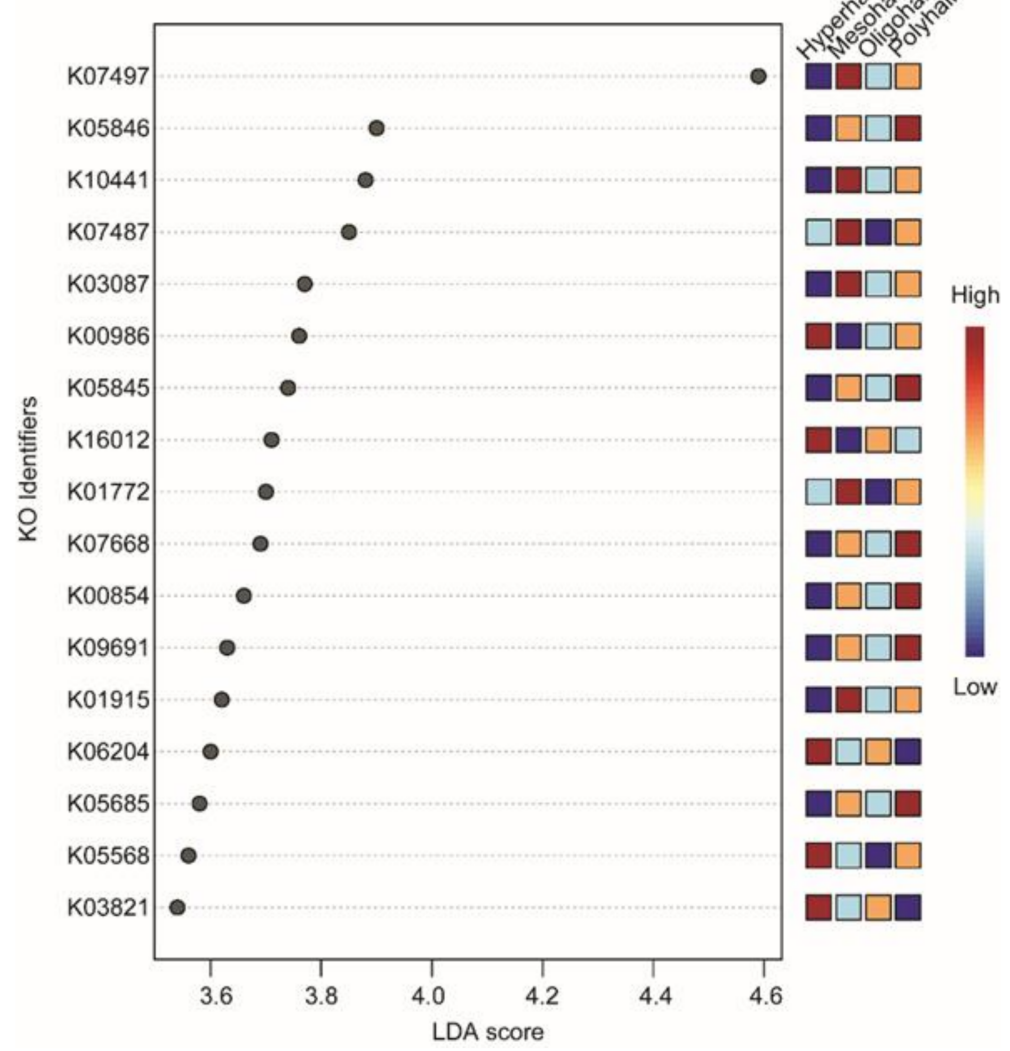

Figure 6. LefSe analysis of predicted functions. LDA score $>3.5$ and False Discovery Rate (FDR)-corrected $p$-value $<0.05$ were considered significant. $\mathrm{KO}$ terms were searched in the KEGG database for annotation.

\section{Discussion}

This study explores the bacterial community composition of 18 remote lakes in western Mongolia with salinity regimes ranging from oligohaline to hyperhaline, situated in arid to semi-arid regions and spanning diverse geographical landscapes. This study is the first to explore the bacterial diversity, composition, and ecology of lakes in western Mongolia. Our findings indicate that both local (water $\mathrm{pH}$, salinity, lake depth) and regional factors (geographical landscape) shape the bacterial community assemblages of these lakes (Figures 4 and 5).

Waters of western Mongolian lakes harbored a wide range of microbial diversity with a Shannon diversity index ranging from 1.69 (DUR-1; hyperhaline) to 3.83 (TAI-3 and TSE-7; mesohaline). 
Mesohaline lakes had higher microbial diversity (Shannon and inverse Simpson) compared to oligohaline, polyhaline, and hyperhaline lakes (Figure 2a,b). Previous studies on lakes of the Qinghai-Tibetan Plateau, China, and the Monegros Desert, Spain [24,46], have identified comparable microbial diversity with the Shannon index ranging from 3.3 to 6.4 and 1.5 to 2.2, respectively. The microbial richness estimator Chao1 for western Mongolian lakes ranged from 30 (TON-1; Hyperhaline) to 152.1 (OIG-3; Polyhaline) (Figure 2c) and was comparatively lower when compared to Qinghai-Tibetan Plateau lakes which ranged from 1012 to 4499; it is worth noting here that Qinghai-Tibetan Plateau lakes range from freshwater to hyperhaline and the sequencing technology (Illumina vs. 454 pyrosequencing) used among the two studies yield contrasting throughputs. Furthermore, the choice of the hypervariable region selected for amplification, amplicon clustering algorithms, and percentage similarity thresholds also affects the outcomes of community diversity analyses [47]. While the current study amplified the V6-V8 hypervariable region and uses a stringent zOTU approach, Yang et al. [24] amplified V3-V4 and clustered OTUs at $97 \%$ similarity. This complicates comparing studies using different approaches and therefore results should be interpreted with caution. In the context of the overall scenario, several studies have found lines of evidence suggesting that microbial diversity decreases with increasing salinity $[24,48]$, and is lowest for hyperhaline lakes, and similar outcomes were observed in our study, reconfirming the previous observations.

Bacterial community composition analysis in the waters of lakes revealed a distinct pattern with the presence of bacterial zOTUs belonging to the phyla Proteobacteria, Actinobacteria, and Bacteroidetes in all 18 lakes' water samples. Genus Cyanobium-PCC6307 (Phylum: Cyanobacteria, Class: Oxyphotobacteria) was dominant in mesohaline lakes (Taigan: TAI, Telmen: TEL, Tsegeen: TSE, and Khag: KHG) and in upper water layers $(0-7 \mathrm{~m})$ of Lake Oigon (OIG), a polyhaline lake. A total of $79 \mathrm{zOTUs}$ were identified belonging to this genus, members of which are capable of performing photosynthesis and have been identified in both higher-altitude freshwater and saline lakes of Tibet as well as in lakes from other parts of the world [49,50]. Three genera, Ca. Aquilina PeM15 and unclassified Microbacteriaceae, and Nitriliruptoria of the phylum Actinobacteria, which are representatives of aerobic heterotrophs, were the dominant groups in polyhaline, mesohaline, and oligohaline lakes but had lower relative abundance in hyperhaline lakes, which have a salinity range of 51.50-335.5 PSU. Psychroflexus, a genus of psychrophilic Bacteroidetes initially isolated from Antarctic sea ice and with genomic features providing the capability to thrive not only in low temperature but also in varying salinity, was the dominant phylum in hyperhaline, whereas other Bacteroidetes genera Flavobacterium and unclassified Flavobacteriaceae were dominant in oligohaline lakes and deeper layers $(7.75-9 \mathrm{~m})$ of the polyhaline OIG lake (Figure 3a,b). The psychroflexus population was also identified to have a recurrent presence and abundance in lakes of Chile and Spain [46,51]. Members of Bacteroidetes have been isolated and cultured from both freshwater and marine environments and have been characterized to play an important role in carbon cycling, including metabolizing cellulose, chitin, and other heavy-molecular weight compounds [52], making them cosmopolitan bacteria in aquatic environments. Other dominant genera were from classes $\alpha$ and $\gamma$-Proteobacteria. Limnohabitans a well-known planktonic bacteria genus of freshwater [19], was dominant in oligohaline lakes, which had the lowest salinity range (0.33-2.27 PSU) in studied lakes. Genera Halomonas and Spiribacter were dominant in hyperhaline lakes, and members of these genera have been classified as moderate halophiles, identified and isolated from environments with moderate to high salinity such as saltern ponds and marine environments [53]. Interestingly, Spiribacter species lack chemolithotrophic capabilities, and no carbon fixation pathways have been detected in the sequenced genomes. Furthermore, the LD29 lineage from phylum Verrucomicrobia had higher relative abundances in TEL and TSE, but low relative abundance in Taigan (TAI) and Khag (KHG) lakes, even though they are mesohaline (Figure 2b). The LD29 lineage and other members of Verrucomicrobia were recently reported to be abundant in a Baltic Sea salinity transect and other brackish water environments [54-56]. Members of Verrucomicrobia are cosmopolitan in origin and found in various aquatic bodies, including rivers and freshwater lakes [11,12,19]. Furthermore, members of Verrucomicrobia can metabolize plankton-derived organic matter [57]. This relationship was observed 
in polyhaline and mesohaline lakes in the current study, which are dominated by pico-cyanobacteria and Verrucomicrobia.

Identification of a highly reduced shared microbiome with only five zOTUs with average relative abundance $>0.1 \%$ among all the lakes belonging to the dominant phyla Proteobacteria and Actinobacteria showcases the cosmopolitan nature of members of these phyla but also points to the tremendous diversity shaped putatively by multiple factors. All these bacterial phyla have been known to harbor bacterial species capable of thriving in various saline environments and contribute a significant proportion of the microbial community in earlier studies as well [23,24,48,58-61].

As microbial communities can be influenced by environmental conditions, variations in the environment both at the local and regional levels could be correlated with microbial community assembly. Since the lakes in our study had diverse physicochemical parameters (Supplementary Table S1) and were also situated in very different geographical landscapes (steppe, Gobi Desert, and forests), it is important to delineate the factors influencing the community composition. Beta-diversity analysis (based on Bray-Curtis dissimilarity) at the zOTU level appeared to cluster lakes based on salinity regimes and geographical landscapes (Figure 3). Furthermore, PERMANOVA (Adonis) analysis suggested that the bacterial community compositions of lakes are governed by salinity (ADONIS salinity $_{3,65}=17.91, p<0.001$ ),

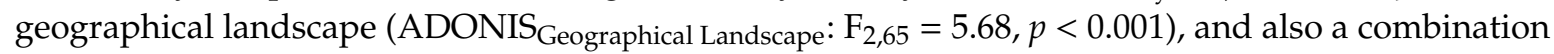
of the two (ADONIS salnity $^{*}$ Geograhical Landscape: $F_{1,65}=6.36, p<0.01$ ). In recent studies, salinity has been proposed to be the major factor driving community dissimilarity among lakes $[9,21,23,24]$, and none have reported the influence of geographical landscape on the community assembly.

CCA analysis at the genus level yielded interesting patterns, as bacterial communities in lakes were significantly related to both local and regional factors (Figure 4). The hypersaline lakes—all from the Gobi Desert-were positively correlated with salinity and arsenic concentration, whereas the mesohaline and polyhaline lakes spanning the forest landscape clustered strongly together and were significantly positively correlated with temperature and depth (Figure 4). Furthermore, all of the lakes in the steppes, irrespective of their salinity regime (mesohaline, polyhaline, and oligohaline), were positively correlated with altitude (Figure 4). Our results highlight the importance of the combination of local and regional factors in influencing bacterial community structures in lakes. Furthermore, the impact of regional factors like geographical distance on community composition and diversity has been reported to be scale-dependent [62]. Local environmental factors are reported to have a higher influence over small spatial scales, whereas regional factors play a significant role when dealing with large distances of tens of thousands of kilometers $[17,62]$. Therefore, our study's clustering of lakes in the same landscape corroborates the scale-dependent influence of regional factors. Further, the influence of local factors in shaping the bacterial community is evident through our results.

The ubiquitous presence of cosmopolitan bacteria at a higher taxonomic rank (phyla Proteobacteria, Actinobacteria, and Bacteroidetes) has been reported in lake waters from lakes in the Qinghan-Tibetan Plateau, Mongolia [24], as well as other regions of the world [17,46]. A comprehensive analysis at the lower taxonomic rank (genus) on western Mongolian lakes suggested habitat specialization of specific taxonomic groups, e.g., Spiribacter, Cyanobium, and Halomonas (Figure 2a,b). Functional prediction using 16S rRNA gene abundance as a proxy to the metabolic profile identified differences in functional traits of lakes from different salinity regimes. Though all the lakes had KO identifiers from ATP-Binding Cassette Transporters as the most significantly different terms, hyperhaline lakes also had K03821 (butanoate metabolism) and K06204 (biofilm formation) as the significantly different KO identifiers compared to other lakes. Interestingly, none of the $\mathrm{KO}$ identifiers were significantly different in oligohaline lakes when compared with other salinity regimes lakes (Figure 6). Identification of different $\mathrm{ABC}$ transporters including the osmoprotectant $\mathrm{ABC}$ transport system (K05845 and K05846), multicomponent $\mathrm{Na}^{+}-\mathrm{H}^{+}$antiporter system (K05568), and carbohydrate metabolism identifiers (K01915, K03821, K00854) shows finer scale functional trait variability of microbes in these lakes. Although it is difficult to identify which bacteria species or groups carry out most of these functions, this observation 
provides preliminary insights into the metabolic functioning of these lakes which should be further explored using a functional metagenomics approach.

\section{Conclusions}

Our study describes, for the first time, the bacterial community composition diversity, richness, and ecological aspects of remote lakes of western Mongolia. High bacterial diversity in meso-, poly-, and oligohaline lakes points out salinity as a major driver for community diversity and the role of bacteria in biogeochemical processes in these lakes. We also identified that both local and regional factors influence the community composition of lakes. These results provide basic information about the very few undisturbed aquatic environments that could help guide future investigations into the long-term environmental impacts on these pristine ecosystems of landlocked Mongolia.

Supplementary Materials: The following are available online at http://www.mdpi.com/2076-2607/8/11/1729/s1, Figure S1: Correlation values of the parameters used to correlate microbial community composition with environmental parameters using canonical correspondence analysis. Table S1: Physicochemical parameter profile of western Mongolian lakes.

Author Contributions: K.T. performed the analysis and wrote the manuscript. B.B., P.-W.C., N.D., and B.O. performed sampling and experiments. K.T., B.B., B.O., and S.-L.T. conceptualized the study. All authors have read and agreed to the published version of the manuscript.

Funding: This study was funded by the Taiwan-Mongolian Joint Project (NSC101-2923-B-001-003-MY3 and TWN_17/002) from the Ministry of Science and Technology, Taiwan and Biodiversity Research Center, Academia Sinica, Taiwan.

Acknowledgments: K.T. would like to acknowledge the Taiwan International Graduate Program (TIGP) for its fellowship.

Conflicts of Interest: The authors declare no conflict of interest.

\section{References}

1. Wurtsbaugh, W.A.; Miller, C.; Null, S.E.; DeRose, R.J.; Wilcock, P.; Hahnenberger, M.; Howe, F.; Moore, J. Decline of the world's saline lakes. Nat. Geosci. 2017, 10, 816-821. [CrossRef]

2. Tranvik, L.J.; Downing, J.A.; Cotner, J.B.; Loiselle, S.A.; Striegl, R.G.; Ballatore, T.J.; Dillon, P.; Finlay, K.; Fortino, K.; Knoll, L.B.; et al. Lakes and reservoirs as regulators of carbon cycling and climate. Limnol. Oceanogr. 2009, 54, 2298-2314. [CrossRef]

3. Tao, S.; Fang, J.; Zhao, X.; Zhao, S.; Shen, H.; Hu, H.; Tang, Z.; Wang, Z.; Guo, Q. Rapid loss of lakes on the Mongolian Plateau. Proc. Natl. Acad. Sci. USA 2015, 112, 2281-2286. [CrossRef] [PubMed]

4. Vörösmarty, C.J.; McIntyre, P.B.; Gessner, M.O.; Dudgeon, D.; Prusevich, A.; Green, P.; Glidden, S.; Bunn, S.E.; Sullivan, C.A.; Liermann, C.R.; et al. Global threats to human water security and river biodiversity. Nature 2010, 467, 555-561. [CrossRef] [PubMed]

5. Saline Lakes: Publications from the 7th International Conference on Salt Lakes, Held in Death Valley National Park, California, USA, September 1999; Melack, J.M.; Jellison, R.; Herbst, D.B., Eds.; Springer: Dordrecht, The Netherlands, 2001; ISBN 978-90-481-5995-6.

6. Sunagawa, S.; Coelho, L.P.; Chaffron, S.; Kultima, J.R.; Labadie, K.; Salazar, G.; Djahanschiri, B.; Zeller, G.; Mende, D.R.; Alberti, A.; et al. Structure and function of the global ocean microbiome. Science 2015, 348, 1261359. [CrossRef]

7. Liu, L.; Yang, J.; Yu, Z.; Wilkinson, D.M. The biogeography of abundant and rare bacterioplankton in the lakes and reservoirs of China. ISME J. 2015, 9, 2068-2077. [CrossRef]

8. Jones, S.E.; Newton, R.J.; McMahon, K.D. Evidence for structuring of bacterial community composition by organic carbon source in temperate lakes. Environ. Microbiol. 2009, 11, 2463-2472. [CrossRef]

9. Baatar, B.; Chiang, P.-W.; Rogozin, D.Y.; Wu, Y.-T.; Tseng, C.-H.; Yang, C.-Y.; Chiu, H.-H.; Oyuntsetseg, B.; Degermendzhy, A.G.; Tang, S.-L. Bacterial Communities of Three Saline Meromictic Lakes in Central Asia. PLoS ONE 2016, 11, e0150847. [CrossRef] 
10. Iliev, I.; Yahubyan, G.; Marhova, M.; Apostolova, E.; Gozmanova, M.; Gecheva, G.; Kostadinova, S.; Ivanova, A.; Baev, V. Metagenomic profiling of the microbial freshwater communities in two Bulgarian reservoirs. J. Basic Microbiol. 2017, 57, 669-679. [CrossRef]

11. Linz, A.M.; Crary, B.C.; Shade, A.; Owens, S.; Gilbert, J.A.; Knight, R.; McMahon, K.D. Bacterial Community Composition and Dynamics Spanning Five Years in Freshwater Bog Lakes. mSphere 2017, 2, e0169-17. [CrossRef] [PubMed]

12. Tandon, K.; Yang, S.-H.; Wan, M.-T.; Yang, C.-C.; Baatar, B.; Chiu, C.-Y.; Tsai, J.-W.; Liu, W.-C.; Tang, S.-L. Bacterial Community in Water and Air of Two Sub-Alpine Lakes in Taiwan. Microbes Environ. 2018, 33, 120-126. [CrossRef]

13. Bowman, J.P.; McCammon, S.A.; Rea, S.M.; McMeekin, T.A. The microbial composition of three limnologically disparate hypersaline Antarctic lakes. FEMS Microbiol. Lett. 2000, 183, 81-88. [CrossRef]

14. Pagaling, E.; Wang, H.; Venables, M.; Wallace, A.; Grant, W.D.; Cowan, D.A.; Jones, B.E.; Ma, Y.; Ventosa, A.; Heaphy, S. Microbial Biogeography of Six Salt Lakes in Inner Mongolia, China, and a Salt Lake in Argentina. Appl. Environ. Microbiol. 2009, 75, 5750-5760. [CrossRef]

15. Zaitseva, S.V.; Abidueva, E.Y.; Radnagurueva, A.A.; Bazarov, S.M.; Buryukhaev, S.P. Structure of Microbial Communities of the Sediments of Alkaline Transbaikalia Lakes with Different Salinity. Microbiology 2018, 87, 559-568. [CrossRef]

16. Selivanova, E.A.; Poshvina, D.V.; Khlopko, Y.A.; Gogoleva, N.E.; Plotnikov, A.O. Diversity of Prokaryotes in Planktonic Communities of Saline Sol-Iletsk lakes (Orenburg Oblast, Russia). Microbiology 2018, 87, 569-582. [CrossRef]

17. Zorz, J.K.; Sharp, C.; Kleiner, M.; Gordon, P.M.K.; Pon, R.T.; Dong, X.; Strous, M. A shared core microbiome in soda lakes separated by large distances. Nat. Commun. 2019, 10, 4230. [CrossRef]

18. Baricz, A.; Chiriac, C.M.; Andrei, A.; Bulzu, P.; Levei, E.A.; Cadar, O.; Battes, K.P.; Cîmpean, M.; Senilă, M.; Cristea, A.; et al. Spatio-temporal insights into microbiology of the freshwater-to-hypersaline, oxic-hypoxic-euxinic waters of Ursu Lake. Environ. Microbiol. 2020. [CrossRef]

19. Newton, R.J.; Jones, S.E.; Eiler, A.; McMahon, K.D.; Bertilsson, S. A Guide to the Natural History of Freshwater Lake Bacteria. Microbiol. Mol. Biol. Rev. 2011, 75, 14-49. [CrossRef]

20. Sorokin, D.Y.; Berben, T.; Melton, E.D.; Overmars, L.; Vavourakis, C.D.; Muyzer, G. Microbial diversity and biogeochemical cycling in soda lakes. Extremophiles 2014, 18, 791-809. [CrossRef]

21. Wu, Q.L.; Zwart, G.; Schauer, M.; Kamst-van Agterveld, M.P.; Hahn, M.W. Bacterioplankton Community Composition along a Salinity Gradient of Sixteen High-Mountain Lakes Located on the Tibetan Plateau, China. Am. Soc. Microbiol. 2006, 72, 5478-5485. [CrossRef]

22. Tang, X.; Xie, G.; Shao, K.; Sai, B.; Chen, Y.; Gao, G. Influence of Salinity on the Bacterial Community Composition in Lake Bosten, a Large Oligosaline Lake in Arid Northwestern China. Appl. Environ. Microbiol. 2012, 78, 4748-4751. [CrossRef]

23. Liu, Y.; Yao, T.; Jiao, N.; Zhu, L.; Hu, A.; Liu, X.; Gao, J.; Chen, Z.-Q. Salinity Impact on Bacterial Community Composition in Five High-Altitude Lakes from the Tibetan Plateau, Western China. Geomicrobiol. J. 2013, 30, 462-469. [CrossRef]

24. Yang, J.; Ma, L.; Jiang, H.; Wu, G.; Dong, H. Salinity shapes microbial diversity and community structure in surface sediments of the Qinghai-Tibetan Lakes. Sci. Rep. 2016, 6, 25078. [CrossRef]

25. Williams, W.D. Salinity as a determinant of the structure of biological communities in salt lakes. Hydrobiologia 1998, 381, 191-201. [CrossRef]

26. He, S.-T.; Zhi, X.-Y.; Jiang, H.; Yang, L.-L.; Wu, J.-Y.; Zhang, Y.-G.; Hozzein, W.N.; Li, W.-J. Biogeography of Nocardiopsis strains from hypersaline environments of Yunnan and Xinjiang Provinces, western China. Sci. Rep. 2015, 5, 13323. [CrossRef]

27. Zhao, F.; Qin, Y.-H.; Zheng, X.; Zhao, H.-W.; Chai, D.-Y.; Li, W.; Pu, M.-X.; Zuo, X.-S.; Qian, W.; Ni, P.; et al. Biogeography and Adaptive evolution of Streptomyces Strains from saline environments. Sci. Rep. 2016, 6, 32718. [CrossRef] [PubMed]

28. Williams, W.D. Chinese and Mongolian saline lakes: A limnological overview. Hydrobiologia 1991, 210, 39-66. [CrossRef]

29. Egorov, A.N. Mongolian salt lakes: Some features of their geography, thermal patterns, chemistry and biology. Hydrobiologia 1993, 267, 13-21. [CrossRef] 
30. Baatar, B.; Chuluun, B.; Tang, S.-L.; Bayanjargal, O.; Oyuntsetseg, B. Vertical distribution of physical-chemical features of water and bottom sediments in four saline lakes of the Khangai mountain region, Western Mongolia. Environ. Earth Sci. 2017, 76, 130. [CrossRef]

31. Bayanmunkh, B.; Sen-Lin, T.; Narangarvuu, D.; Ochirkhuyag, B.; Bolormaa, O. Physico-Chemical Composition of Saline Lakes of the Gobi Desert Region, Western Mongolia. J. Earth Sci. Clim. Chang. 2017, 8. [CrossRef]

32. Chen, C.-P.; Tseng, C.-H.; Chen, C.A.; Tang, S.-L. The dynamics of microbial partnerships in the coral Isopora palifera. ISME J. 2011, 5, 728-740. [CrossRef] [PubMed]

33. Jorgensen, S.L.; Hannisdal, B.; Lanzen, A.; Baumberger, T.; Flesland, K.; Fonseca, R.; Ovreas, L.; Steen, I.H.; Thorseth, I.H.; Pedersen, R.B.; et al. Correlating microbial community profiles with geochemical data in highly stratified sediments from the Arctic Mid-Ocean Ridge. Proc. Natl. Acad. Sci. USA 2012, 109, E2846-E2855. [CrossRef]

34. Schloss, P.D.; Westcott, S.L.; Ryabin, T.; Hall, J.R.; Hartmann, M.; Hollister, E.B.; Lesniewski, R.A.; Oakley, B.B.; Parks, D.H.; Robinson, C.J.; et al. Introducing mothur: Open-Source, Platform-Independent, Community-Supported Software for Describing and Comparing Microbial Communities. Am. Soc. Microbiol. 2009, 75, 7537-7541. [CrossRef] [PubMed]

35. Edgar, R.C.; Haas, B.J.; Clemente, J.C.; Quince, C.; Knight, R. UCHIME improves sensitivity and speed of chimera detection. Bioinformatics 2011, 27, 2194-2200. [CrossRef]

36. Edgar, R.C. UPARSE: Highly accurate OTU sequences from microbial amplicon reads. Nat. Methods 2013, 10, 996-998. [CrossRef] [PubMed]

37. Edgar, R.C. UNOISE2: Improved error-correction for illumina $16 \mathrm{~S}$ and ITS amplicon sequencing. BioRxiv 2016, 081257.

38. Quast, C.; Pruesse, E.; Yilmaz, P.; Gerken, J.; Schweer, T.; Yarza, P.; Peplies, J.; Glöckner, F.O. The SILVA ribosomal RNA gene database project: Improved data processing and web-based tools. Nucleic Acids Res. 2012, 41, D590-D596. [CrossRef]

39. Yilmaz, P.; Parfrey, L.W.; Yarza, P.; Gerken, J.; Pruesse, E.; Quast, C.; Schweer, T.; Peplies, J.; Ludwig, W.; Glöckner, F.O. The SILVA and "All-species Living Tree Project (LTP)" taxonomic frameworks. Nucl. Acids Res. 2014, 42, D643-D648. [CrossRef]

40. Wickham, H. Ggplot2: Elegant Graphics for Data Analysis; Springer: New York, NY, USA, 2016; ISBN 978-3-319-24277-4.

41. McMurdie, P.J.; Holmes, S. phyloseq: An R Package for Reproducible Interactive Analysis and Graphics of Microbiome Census Data. PLoS ONE 2013, 8, e61217. [CrossRef]

42. Oksanen, J.; Blanchet, F.G.; Friendly, M.; Kindt, R.; Legendre, P.; McGlinn, D.; Minchin, P.R.; O’Hara, R.B.; Simpson, G.L.; Solymos, P.; et al. Vegan: Community Ecology Package. 2019. Available online: https://www.researchgate.net/publication/313502495_Vegan_Community_Ecology_Package (accessed on 10 January 2020).

43. Wemheuer, F.; Taylor, J.A.; Daniel, R.; Johnston, E.; Meinicke, P.; Thomas, T.; Wemheuer, B. Tax4Fun2: Prediction of habitat-specific functional profiles and functional redundancy based on 16S rRNA gene sequences. Environ. Microbiome 2020, 15, 11. [CrossRef]

44. Dhariwal, A.; Chong, J.; Habib, S.; King, I.L.; Agellon, L.B.; Xia, J. MicrobiomeAnalyst: A web-based tool for comprehensive statistical, visual and meta-analysis of microbiome data. Nucleic Acids Res. 2017, 45, W180-W188. [CrossRef] [PubMed]

45. Chong, J.; Liu, P.; Zhou, G.; Xia, J. Using MicrobiomeAnalyst for comprehensive statistical, functional, and meta-analysis of microbiome data. Nat. Protoc. 2020, 15, 799-821. [CrossRef]

46. Casamayor, E.O.; Triadó-Margarit, X.; Castañeda, C. Microbial biodiversity in saline shallow lakes of the Monegros Desert, Spain. FEMS Microbiol. Ecol. 2013, 85, 503-518. [CrossRef] [PubMed]

47. Bukin, Y.S.; Galachyants, Y.P.; Morozov, I.V.; Bukin, S.V.; Zakharenko, A.S.; Zemskaya, T.I. The effect of $16 \mathrm{~S}$ rRNA region choice on bacterial community metabarcoding results. Sci. Data 2019, 6, 190007. [CrossRef]

48. Oren, A.; Naftz, D.L.; Palacios, P.; Wurtsbaugh, W.A. Saline lakes around the world: Unique systems with unique values. In Proceedings of the 10th ISSLR Conference and 2008 FRIENDS of Great Salt Lake Forum, Salt Lake City, UT, USA, 11-16 May 2008; Volume 15, p. 267.

49. Huang, S.; Liu, Y.; Hu, A.; Liu, X.; Chen, F.; Yao, T.; Jiao, N. Genetic Diversity of Picocyanobacteria in Tibetan Lakes: Assessing the Endemic and Universal Distributions. Appl. Environ. Microbiol. 2014, 80, 7640-7650. [CrossRef] [PubMed] 
50. Felföldi, T. Microbial communities of soda lakes and pans in the Carpathian Basin: A review. Biologia Futura 2020. [CrossRef]

51. Demergasso, C.; Escudero, L.; Casamayor, E.O.; Chong, G.; Balagué, V.; Pedrós-Alió, C. Novelty and spatio-temporal heterogeneity in the bacterial diversity of hypersaline Lake Tebenquiche (Salar de Atacama). Extremophiles 2008, 12, 491-504. [CrossRef]

52. Abell, G.C.J.; Bowman, J.P. Ecological and biogeographic relationships of class Flavobacteria in the Southern Ocean. FEMS Microbiol. Ecol. 2005, 51, 265-277. [CrossRef]

53. López-Pérez, M.; Ghai, R.; Leon, M.; Rodríguez-Olmos, Á.; Copa-Patiño, J.; Soliveri, J.; Sanchez-Porro, C.; Ventosa, A.; Rodriguez-Valera, F. Genomes of "Spiribacter", a streamlined, successful halophilic bacterium. BMC Genom. 2013, 14, 787. [CrossRef]

54. Riemann, L.; Leitet, C.; Pommier, T.; Simu, K.; Holmfeldt, K.; Larsson, U.; Hagström, Å. The Native Bacterioplankton Community in the Central Baltic Sea Is Influenced by Freshwater Bacterial Species. Am. Soc. Microbiol. 2008, 74, 503-515. [CrossRef]

55. Lindsay, M.R.; Anderson, C.; Fox, N.; Scofield, G.; Allen, J.; Anderson, E.; Bueter, L.; Poudel, S.; Sutherland, K.; Munson-McGee, J.H.; et al. Microbialite response to an anthropogenic salinity gradient in Great Salt Lake, Utah. Geobiology 2017, 15, 131-145. [CrossRef]

56. Bergen, B.; Herlemann, D.P.R.; Labrenz, M.; Jürgens, K. Distribution of the verrucomicrobial clade $S$ partobacteria along a salinity gradient in the Baltic Sea: Quantifying Verrucomicrobia in the Baltic Sea. Environ. Microbiol. Rep. 2014, 6, 625-630. [CrossRef]

57. Orsi, W.D.; Smith, J.M.; Liu, S.; Liu, Z.; Sakamoto, C.M.; Wilken, S.; Poirier, C.; Richards, T.A.; Keeling, P.J.; Worden, A.Z.; et al. Diverse, uncultivated bacteria and archaea underlying the cycling of dissolved protein in the ocean. ISME J. 2016, 10, 2158-2173. [CrossRef]

58. Kirchman, D.L.; Dittel, A.I.; Malmstrom, R.R.; Cottrell, M.T. Biogeography of major bacterial groups in the Delaware Estuary. Limnol. Oceanogr. 2005, 50, 1697-1706. [CrossRef]

59. Campbell, B.J.; Kirchman, D.L. Bacterial diversity, community structure and potential growth rates along an estuarine salinity gradient. ISME J. 2013, 7, 210-220. [CrossRef] [PubMed]

60. Bell, T.A.S.; Sen-Kilic, E.; Felföldi, T.; Vasas, G.; Fields, M.W.; Peyton, B.M. Microbial community changes during a toxic cyanobacterial bloom in an alkaline Hungarian lake. Antonie van Leeuwenhoek 2018, 111, 2425-2440. [CrossRef]

61. Bullerjahn, G.S.; McKay, R.M.L.; Bernát, G.; Prášil, O.; Vörös, L.; Pálffy, K.; Tugyi, N.; Somogyi, B. Community dynamics and function of algae and bacteria during winter in central European great lakes. J. Great Lakes Res. 2020, 46, 732-740. [CrossRef]

62. Martiny, J.B.H.; Eisen, J.A.; Penn, K.; Allison, S.D.; Horner-Devine, M.C. Drivers of bacterial -diversity depend on spatial scale. Proc. Natl. Acad. Sci. USA 2011, 108, 7850-7854. [CrossRef]

Publisher's Note: MDPI stays neutral with regard to jurisdictional claims in published maps and institutional affiliations.

(C) 2020 by the authors. Licensee MDPI, Basel, Switzerland. This article is an open access article distributed under the terms and conditions of the Creative Commons Attribution (CC BY) license (http://creativecommons.org/licenses/by/4.0/). 